\title{
Narrative reinventions as cognitive mechanisms for public policy stability: the case of anti-drug policy in Colombia
}

\author{
Jairo Santander 1 \\ 1 Universidad de los Andes / Centro de Estudios Interdisciplinarios sobre Desarrollo, Bogotá - Colombia
}

Public policies face major challenges to their consolidation and stability that force rulers to make significant political efforts to keep them alive. Some of these challenges occur by the adjustment of the policy's idea as an attempt to reduce the possible difficulties caused by public confrontation, thus better adapting them to the reference frame of the actors. Such is the case of Colombia's drug control policy which did not have sufficient legitimacy to be carried out, despite international pressure, but it was later coupled to the international agenda as a national need. By using the critical discourse analysis, this study verifies how the discursive transformation of this policy took place and the cognitive mechanisms used to reinterpret it as a matter of national security and not international co-responsibility, which allowed consolidation of the current prohibitionist strategy. The results of the study reveal an interpretation of the drug trafficking problem as a threat to the institutional order, which reduces the confrontation capacity of the critics of the proposed policy.

Keywords: agenda setting; policy dynamics; cognitive mechanism; policy stability; antidrug policy.

\section{Reinvenções narrativas como mecanismos cognitivos para a estabilidade de políticas públicas: 0 caso da política antidrogas na Colômbia}

Frequentemente, as políticas públicas enfrentam desafios importantes para sua consolidação e estabilidade, e acabam exigindo esforços políticos significativos para manter-se à tona. Parte destes desafios ocorre ao ajustar a ideia de política para tentar diminuir possíveis impasses originados pelo confronto público. No caso da política de controle de drogas na Colômbia, apesar da pressão internacional, inicialmente não havia legitimidade suficiente para sua execução. Através da análise crítica do discurso, o presente estudo verifica como ocorreu a transformação discursiva desta política e quais foram os mecanismos cognitivos utilizados para que pudesse ser reinterpretada como uma questão de segurança nacional e não de corresponsabilidade internacional, o que permitiu a consolidação da estratégia proibicionista vigente. Os resultados do estudo revelam uma interpretação do problema do narcotráfico como uma ameaça à ordem institucional, o que levou a uma diminuição da capacidade de confrontar criticamente a política proposta.

Palavras-chave: definição de agenda; dinâmica de políticas; mecanismo cognitivo; estabilidade de políticas; política antidroga.

\section{Reinvenciones narrativas como mecanismos cognitivos de estabilidad de políticas públicas: el caso de la política antidrogas en Colombia}

Muchas políticas enfrentan importantes desafíos para su consolidación y estabilidad y exigen esfuerzos políticos significativos para mantenerse en vigor. Parte de estos desafíos se dan al ajustar la idea de política para solventar los impases de la confrontación pública. Como en el caso de la política de lucha contra las drogas en Colombia, que al principio no contaba con la legitimidad suficiente para su ejecución, a pesar de la presión internacional. El presente estudio, a través de un análisis crítico del discurso, analiza cómo se dio la transformación discursiva de esta política y cuáles fueron los mecanismos cognitivos utilizados para que se reinterpretara como un asunto de seguridad nacional más que de corresponsabilidad internacional, lo que permitió la consolidación de la estrategia prohibicionista que sigue vigente. Los resultados del estudio revelan una interpretación del problema del narcotráfico como una amenaza al orden institucional, lo que llevó a una disminución de la capacidad de confrontar críticamente la política propuesta.

Palabras clave: establecimiento de agenda; dinámica de políticas; mecanismos cognitivos; estabilidad de políticas; política antidrogas. 


\section{INTRODUCTION}

In Latin America, political disappointment, lack of legitimacy and results make public policies to be constantly facing disassembly and transformation tensions. These difficulties frustrate policy continuity and lead to a scenario of deep government instability that is considered a feature of the countries in the region (Brinks, Levitsky, \& Murillo, 2019).

Therefore, governments address their efforts to maintain the continuity of policies in the face of the government instability. So, although some authors such as Majone (1989) argue that stability depends on society's perception about the efficiency of the policy, this is a remote scenario in the region. In Latin America, many policies get consolidated in the government agenda despite the inconsistent institutional scenario, the constant social perception of failure and its lack of success.

A clear example of this is the anti-drugs policy that has been implemented for almost forty years in several Latin American countries, and in particular in Colombia. The strategy, which has a clear repressive component at its core, has constantly been in the eye of the critics and, despite this, it has remained a solid imagen.

In these scenarios, governors use multiple mechanisms to ensure that policies under pressure of change can overcome it and remain stable. Normative and budgetary mechanisms of government are part of the menu, but there are also cognitive artifacts, related to the argumentation and construction of the policy idea, which are used to overcome the impasses of confrontation in the public sphere (Sabatier \& Jenkins-Smith, 1999; Schlager, 2007; Weible \& Jenkins-Smith, 2016; Weible \& Sabatier, 2006; Zittoun, 2009).

Thus, it is usual that, as stated by the advocacy coalition (ACF) approach, both the idea and its argumentation need to be adjusted to accommodate changes in the political environment in order to avoid substantial change (Sabatier \& Weible, 2007). But there are also severe interpretative changes that are made to stabilize. Therefore, not all reinterpretations or changes in the framework of the problem imply a transformation of the policy, as suggested by the punctuated equilibrium (PE) approach. And sometimes, wider changes in the definition or interpretation of a problem seek a better fit with the current beliefs system to ensure stability.

The case of anti-drug policy in Colombia is interesting to analyze from this cognitive dimension. At the beginning, it was an imported strategy that generated strong social resistance and made difficult its consolidation. However, subsequently, the government adjusted the interpretation of the problem allowing it to solidify, despite the fact that it has been the subject of constant social debate about its desirability and permanence (Gaviria \& Mejía, 2011).

It is therefore important to understand how the policy idea managed to adjust to consolidate and remain for more than thirty years, despite the high social costs of the strategy and the constant criticism and pressures for change. Mainly at the beginning, when the political support required to consolidate the vision of the problem in the public agenda was unstable, and the social actors felt it was somebody else's problem.

Keeping an idea on the institutional agenda is as complex as entering it or transforming it. That is why the answer is not either efficiency or inertia, which are the most common answers in the literature (Peters, 2016). In fact, there is enough political activity to keep stable such a questioned policy, and 
among the mechanisms are changes in discourse, gradual or severe, that adjust the idea of the policy (Reynares, 2017; Weible, Sabatier, \& McQueen, 2009).

As stated by Zittoun (2009), understanding changes in discourse is fundamental to understanding the dynamics of public policy. For this reason, part of this paper is dedicated to generating an analytical framework that allows the identification of the stability mechanisms associated with the construction and discursive transformation of the idea.

In order to clarify the question, this paper intends to reconstruct the discursive process of anti-drug policy in Colombia during the period of its formation in the 1980s, and through this, identify the narrative mechanisms that were employed by government actors to achieve the necessary legitimacy and the consolidation of the strategy. The case is relevant for testing the analytical framework because the anti-drug policy discourse is considered to have adjusted in order to overcome the social perception that the problem was foreign and make it a problem of the country, mainly associated with national security issues.

This document reviews the characteristics and dimensions of the discussion on stability of an idea of policy, within the framework of the study of public policy dynamics; it then proposes a classification of types of cognitive mechanisms of stability. Thereafter, the paper shows a critic analysis of the discourse on the public discussion about the war against drugs at the beginning of the problem in the 1980s, in order to identify the key moments of adjustment that intended to guarantee the continuity of the public policy idea.

\section{STABILITY PROCESSES AND COGNITIVE MECHANISMS}

\subsection{Stability in public policy dynamics}

For Majone (1989, p. 95), "both continuity and change are inherent in the conception of public policy". This is due to the fact that a public policy, in order to be recognized as such, requires a consistent and stable component (Zittoun, 2009), which is socially identifiable; but this can only be delimited in a joint understanding of the events of change, as proposed by the studies on the dynamics of policies (Capano, 2009; Capano \& Howlett, 2009). In other words, in order to give a public policy an identity, the question must be resolved: how do I know that it has really changed?

After a thorough review on the ways to give answers to this question, the premise of Real-Dato (2009) about the heterogeneity of approaches to the dynamics about change and stability is still in force (See Peters \& Zittoun, 2016). So, the existence of a neat literature, from authors that are not used to communicate with each other, has led to real analytical difficulties inside the different approaches. Some of them expressed in epistemological and theoretical inconsistencies associated, among others, with the logic of progression (graduality or interruption), or the role of the institutional structure and political agency (Capano, 2009; Real-Dato, 2009a; Zahariadis, 2016), as well as methodological challenges associated with defining the best way to measure change and consistency (Kay, 2009; Sabatier, 2007; Zittoun, 2009).

At this point the research faces the analytical difficulty of a varied conceptualization of the stability which becomes even more complex because most approaches are too focused on change. Depending on the approach, this is understood as a result of the inertia, as in the case of the Multiple Streams 
Fremawork (MSF) (Kingdon, 1984; Zahariadis, 2007, 2016); of a locking scenario, due to institutional restrictions, as in some institutionalists (Pereira, Singh, \& Mueller, 2011; Peters, 2016; Polski \& Ostrom, 1999; Tsebelis, 2002); or the product of evolutionary-incremental dynamics, such as the PE approach (Eissler, Russell, \& Jones, 2016; Jones, 2002; True, Jones, \& Baumgartner, 2007), the ACF (Sabatier, 1988; Weible et al., 2009) and historical institutionalism (HI) (Jacobs, 2010; Rayner, 2009; Sven Steinmo \& Longstreth, 1992; Thelen, 2010).

What is clear from this multiplicity of conceptualizations is that a better understanding of the place of stability in the dynamics requires three important elements: that there is no single route to stability, that change is also used as a stabilization mechanism and that more clarity is needed on how political processes are activated within the government scenario in the face of environmental disturbances (Capano, 2009).

Because of the enormous efforts that governments and political actors make to consolidate and maintain an policy idea, it is understood that stability cannot be considered a simple passive stage of the dynamic and that, on the contrary, behind it there is a broad process of political action and government, which configures the arena of action and determines the trajectory of State intervention.

Understanding stability as a political process requires an integrative approach, which recognizes that it can have different sources of initiation and mechanisms of progressivity (Capano \& Howlett, 2009; Greif \& Laitin, 2004; Lindner, 2003)(b, in which the structural and agential factors are related, and where the actors have an important discretionary power and capacity of action to guide the processes of stabilization, in reaction to a changing political environment.

In this political process, an important part of the efforts is focused on consolidating a policy idea that has an impact on the consolidation of the government scenario. For example, for the EP approach, the stability process is that of the subsystem policy, in which stability is achieved through the issue framing of the problem. This involves the configuration and reaffirmation of a policy image, understood as empirical information and emotional interpellations connected with political values that transmit an idea of policy to the public and allow the consolidation of a stable institutional structure that translates into a monopoly of policy (True et al., 2007). It is similar in the ACF approach, where the formation of a stable system of beliefs facilitates the formation of advocacy coalitions of the policy (Sabatier, 1988; Weible \& Jenkins-Smith, 2016; Weible, Sabatier, \& McQueen, 2008).

The process may also involve a trajectory constraint, as posed by institutionalist approaches, where stability is not understood as a static image (a photograph), but as a whole political process in which the idea of the policy will later limit the decisional discretion of governors (Pierson, 2000). In this way, political actors will act to condition policy decisions in the future and patterns of action and decision are formed to guide the behavior of actors in the public policy space (Jacobs, 2010) and restrict other possible options, limiting the possibility of change.

By integrating approaches, stability can be considered as the presence of a consolidated core of interpretation, of beliefs about public policy, its purposes and values (Majone, 1989, 1996). A core that will condition the set of policy options and produce an agreement of social adhesion to an already existing idea and structure of government.

This core is not only protected through variations of adaptation, which seek to dilute the pressures for change, as proposed by (Baumgartner \& Jones, 2002), but can also involve important changes in 
narratives, values to which they are associated or purposes that allow better adaptation to the belief system of agents in the public sphere. So not all variation implies transformation, given that many times these are made precisely to stabilize its core.

\subsection{Cognitive change mechanisms for the public policy stability}

The consolidation of an idea is a process, and it is not just a matter of opportunity, as Kingdon suggests, but it needs a specific type of discursive activity, of persuasion, both from rulers and policy entrepreneurs, to unite the problem and its preferred solution. This process, which includes both discursive and relational efforts (Majone, 1989), generally requires not only the production of arguments to support the solution, but also the reformulation of the problem itself and an adjustment of the solutions based on this reformulation (Zittoun, 2009). So, the question is not whether persuasion or argument is required to consolidate a public policy, but what form it takes and when (Majone, 1989).

For Thelen (1999), an understanding of how the logics of stability and change are intertwined requires the identification of the mechanisms that reproduce and feedback them, in order to identify, in turn, how they can be fractured (which would be the door to change). The mechanisms can be of various types. For Tilly (2001), among others, are the relational ones, which alter connections between people, groups and interpersonal networks; and the cognitive ones, that operate through alterations on individual and collective perceptions.

Public policy formulation represents the interpretations of the belief systems of political actors (Weible \& Jenkins-Smith, 2016). Therefore, the persuasive process seeks to guarantee stability by consolidating a shared, widely disseminated mental map that facilitates a joint interpretation of reality (Denzau \& North, 1994). This promotes the relative strengthening of the group of actors whose interpretation will influence the public discussion scenarios, which will help to transcend the idea of the policy to future decision-making moments.

In many cases this construction of a shared mind map is only achieved through gradual or radical changes in the political narrative, because with them it is possible to diminish the discrepancies of the policy idea with the current system of beliefs. Thus, political actors activate the cognitive mechanisms to achieve either an increase in the legitimacy of the idea of the policy, the adhesion of more defenders, greater commitment from those already existing, or a decrease in the validity of the discourse of the contradictory coalition. According to the type of cognitive transformation that takes place, two groups of mechanisms can be distinguished: i. Marginal adjustments; and ii. Interpretative reinventions.

Marginal adjustment mechanisms act on the periphery (secondary objectives, action lines or complementary programs), oxygenating the idea and implying that there is a process of continuous improvement and adaptation to the new realities of the problem. In this way, as stated in the ACF, the aim is to ensure that the policy will not transcend into a larger discussion scenario that puts its continuity at risk (Weible et al., 2009).

This kind of mechanisms seek to show a proactive attitude on the part of the government through of variations in the second order components of the policy. There are also those that seek to show a receptive capacity to recognize needs for improvement, such as the elimination of peripheric components that are the object of criticism or that are evidencing a malfunction in practice, as well the exclusion or modification of conflicting concepts or definitions. 
For their part, reinterpretations do not only serve to bring about change, as proposed by the PE with the concept of refreaming (Eissler et al., 2016). They also serve to consolidate a policy solution by altering the problem-solution relationship (Zittoun, 2009). What happens when political actors manage to alter the perception of the policy through an apparent functional transformation of it, but, keeps the essence of the core intact. This can happen in two ways. First, by reinterpreting the nature of the problem, where a new problem to be solved with the already existing strategy is posed (reinterpretation of the problem Aguilar, 2003); second, by reinterpreting the extent of the problem, where it is argued that the problem has new dimensions that need to be addressed by the policy (eg. in addition to export traffic, domestic consumption traffic must be combated). The latter usually leads to marginal policy adjustments.

This type of mechanism is used when the pressure for change makes it difficult to sustain policy idea through marginal improvements. This happens when the policy seems unjustifiable for the purpose created and the coalition for change has broad legitimacy in public opinion.

In summary, the broad set of cognitive mechanisms reflects that policy makers have several ways to generate changes in the perception of network actors in order to keep the policy idea stable. These adjustments allow in practice to improve the government environment through a narrative that showcases an active government, which seeks to adjust and correct faults, which can help improve support for government action, or at least provide a waiting compass, hoping that the interest of those making demands for change will fade.

\section{DISCOURSE ANALYSIS FOR THE IDENTIFICATION OF COGNITIVE MECHANISMS}

The present study approaches the problem from a methodological framework of critical discourse analysis. This is because the question of how governments manage to stabilize the idea of anti-drug policy fits well among the concerns of critical discourse analysis, which is centered on the use of public discourse as a mechanism of domination, control, and power that influences the actions of policy actors (Van Dijk, 2015). The approach employed comprises the discourse of politics beyond official discourses. Thus, the discourse includes all the words and phrases that are used by all relevant actors in the political space and during the whole process of policy formation (Zittoun, 2009).

For this analysis, Van Dijk's approach was followed, seeking to provide a systematic explanation of the complex structures and strategies of discourse. The analysis aims at the reconstruction of the communicative event (scenario, participants and objectives) that is behind the discourse, and the impact of its narrative on social cognition, mainly on future public policy decisions and the position of critical actors.

Thus, the analysis focuses on the interventions made by the relevant actors, both promoters and detractors of the policy, in which they express their positions on the policy and its development process.

The analysis of the persuasive process is carried out in three dimensions: the linguistic, the intertextual and the social (Fairclough, 2003). In the linguistic dimension, vocabulary, grammar, cohesion and textual structures are analyzed to identify how these shape discourse, its meaning and 
significance. This to show hypotheses about the social relations and identities that are constructed, and visions about the knowledge and belief systems present in the discourse.

The intertextual dimension understands that discourses are formed in relation to others. Relationship both situational, which implies at the moment that the speech takes place, and sequential, in relation to the trajectory of the speech as well as to other previous narratives that feed it; in order to identify how these are transformed in time, adjusted in response or supported by fragments of other texts, with which they are related by means of assimilation, contradiction or criticism.

Finally, political discourse is analyzed in relation to its ideological and hegemonic impact. The first implies to analyze the meanings or configurations of reality as product and contribution to the production, reproduction and transformation of the domination relations. And the second implies reviewing the discourse as part of the hegemonic dispute and tool of power groups.

Thus, the unit of record of the linguistic component is the textual structures that reference defense and criticism of the components of the policy. The intertextual analysis examines the sequence of the discourse, understanding the variation of the narrative of defense as a coherent reaction to the critical speeches. And the social component of the study leads to the analysis of the construction of the reality of the problem contained in the narratives and its use to achieve victory in the public sphere. The investigation is based on the content analysis method. In this case, of the discourses of policy makers and change agents and, the content analysis of public policy documents.

Categorization is carried out in relation to the intertextual dimension, which is the one that gives the most account of the dynamics of political discourse. This allows to order the information collected in analytical units, associated to the reconstruction of containment processes. Thus, Box 1 sets out the main categories for the argument units that allow to order the data coming from the content analysis through the NVivo software.

BOX 1 UNITS OF REGISTRATION IN THE CONTENTS

\begin{tabular}{|c|c|}
\hline Critical Line & $\begin{array}{l}\text { Arguments of the public } \\
\text { policy }\end{array}$ \\
\hline Critics of the public policy & Of validation of public policy relevance \\
\hline Of change dunning of the public policy & Of reply of critics \\
\hline $\begin{array}{l}\text { Arguments of only one part of the policy } \\
\text { claim }\end{array}$ & introduction of policy adjustments. \\
\hline $\begin{array}{l}\text { Of change complaint and alternative } \\
\text { proposal }\end{array}$ & Arguments for reversing alternatives \\
\hline
\end{tabular}

Source: Elaborated by the author. 
For this research, a matrix of press releases and official speeches was designed and it contains around 207 references from the entire study period, which runs from 1979 to 1989, which were selected under the criteria of containing discursive expressions or interviews of the main actors in the political government space (both defenders and critics). The search was made through a work of archive and word relations keys for the historical process of the policy for fighting against drugs.

Finally, for obtaining a triangulation to strengthen the content analysis, secondary sources that have analyzed the evolution of the fight against drugs were used. For this purpose, research documents, monographs and historical records were consulted.

\section{CONSOLIDATION OF DRUG TRAFFICKING AS AN ISSUE ON THE PUBLIC AGENDA AND STABILIZATION OF THE Fight AGAINST DRUGS (1979-1989)}

\subsection{The beginnings of the war on drugs: the first narratives}

The war on drugs was an imported strategy, supported by the policy guidelines issued by the U.S. government, enacted in the early 1970s (Gaviria \& Mejia, 2011). This discourse takes the problem to the side of supply, stated that if there was production there would be consumption (Tokatlian, 2000a). Thus, from the beginning, the core of the policy was oriented from a punitive and prohibitionist approach, understanding the problem as an object of criminal policy, and centering the action toward the control of the illicit offer of drugs.

In this way, and although this was an issue alien to the national problems, in Colombia, as in several Latin American countries, enormous public resources are beginning to be directed towards tackling the problem, despite the fact that the country was much more concerned about the institutional weakness of the State and the fragility of its economic structure (matters pertaining to the extensive modernization efforts that had been carried out).

As an imported problem, the fight against drugs for the Colombian government began to be more a matter of co-responsibility with the international community. And, as can be seen in Box 2, the US government encouraged this argument, in which the producing countries had a duty despite not facing problems of drug addiction in their territories (Thoumi, 2006; Tokatlian, 1990).

BOX 2

PRONOUNCEMENTS OF U.S. REPRESENTATIVES

Lee Dogoloff (Assistant of President Carter for Drug Affairs) Diego Asencio (U.S. Ambassador to Colombia)
"Crop eradication offers another opportunity to reduce the "President Turbay has taken a vigorous and uncompromising
supply of illicit drugs from their source... This strategy has stand against the trafficking of illicit narcotics... 'The campaign
proven to be the most efficient method to reduce illegal in La Guajira is a model in its genre and is recognized as such
cultivation in those countries that do not have a deep history of in my government'.".
poppy cultivation and opium use".

Source: El Tiempo (1979a, p. 8A). 
The narrative of co-responsibility was given, in part, because the Colombian government adhered to international conventions, which obliged to act on the problem (Thoumi, 2009). In addition, the objectives of the war on drugs were the central point of US government interests in the region (Thoumi, 2006). These created an institutional restriction, which would exogenously force the Colombian government to seek to convince society of the need to confront the problem and to configure the best policy scenario. This impediment was constantly remembered from Washington:

I am not convinced by the argument that the only way to end the tasks of this business is to legalize its marketing. In addition to the counter-arguments related to the international conventions that Colombia has signed... there is another factor that seems to me primordial... How would it be possible to legalize the trafficking of marijuana unilaterally...? I imagine that the society that tried it will become a pirate nation... (El Tiempo, 1979b, p. 8A).

But, from the beginning, the problem proved to be more complex than expected. An explosion of marijuana production in the north of the country (the marimbera bonanza) demonstrated the complexity of the challenge (León, Atehortúa, \& Rojas, 2008; Santander, 2009; Sarmiento \& Moreno, 1990). This triggered the alarms in the public sphere, where they began to question the justifications on the reason for giving that fight.

\subsection{The public discussion: moralism, legalization and extradition}

In the late 1970s, when actions against drug trafficking were increasing in intensity, social and public acceptance of the international view of the drug problem was very low (Peñaranda, 2009). Almost $44 \%$ of the population considered that marijuana was less or equally harmful to alcohol, a drink that was legal; and less than $2 \%$ of Colombians consumed, so a very small part of the production went to supply the domestic market (Vargas, 2010).

But there was also public resistance because various sectors of society, including broad traditional political and economic sectors, saw drug trafficking as positive for the Colombian economy. Resistance that had its dark side. Several drug traffickers and related politicians promoted ideas of benefit to local development and nationalist doctrines. This was the case of Carlos Lehder, who formed a political movement in his home region, Quindío, called the National Latin Movement, where he encouraged a positive view of drug trafficking. His two battle phrases were "Marijuana is for the people" and "Cocaine is for milking the rich" El "loquito" Carlos (Semana magazine, 1987, p. 23).

That is why the Colombian government, together with broad sectors of civil society, had to make a fierce defense of the policy. In order to do this, and given that the argument of co-responsibility did not permeate public opinion, the defenders began to change their discourse arguing that although the problem of consumption was not a problem for the country, not to confront the production of narcotics and to collaborate with the international fight was a very serious moral failure that attempted against the ethical principles of the nation. This was evident in the public interventions of those who defended the measure (see Box 3). 


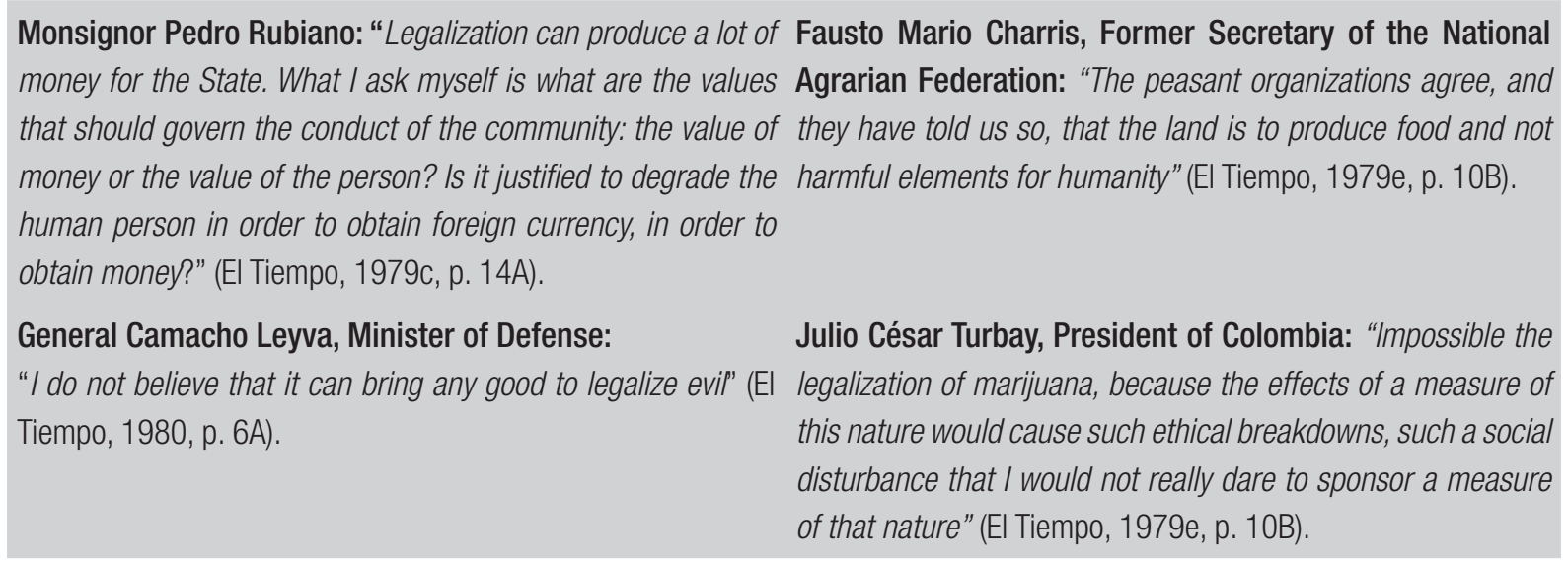

Source: Elaborated by the author.

But this new argument did not consolidate into public agenda. The social costs of the war on drugs and public resistance began to increase and various actors began to make visible that drug trafficking generated a scenario of corruption and violence that altered the institutional order, only avoidable with legalization (Santos, 1979; Tokatlian, 2000b). This was the position of policy entrepreneurs who were against politics, as in the case of one of the most important trade union leaders in the country, Ernesto Samper, the president of the National Association of Financial Institutions, who proposed legalization as the solution to the moral problem facing the country (Samper, 1979).

In the State, such important figures as the General Comptroller of the Republic, magistrates of high courts, congressmen and the military were in favor of Samper's proposal (El Tiempo, 1979c; Tokatlian, 2000b). The same happened at the regional level, where they also demonstrated in favour of legalization, especially in areas where there had been a major influence of the so-called Marimbera Bonanza. For example, the mayor of Valledupar said that, "to a certain extent, legalization can be beneficial for the country" (El Tiempo, 1979c, p. 14A).

The public discussion situation was critical. The political support required to consolidate the vision of the problem on the public agenda was unstable, and key actors were not fully guaranteed. Proof of this was the open opposition of Senate President, Héctor Echeverri, who, along with other Senators, began to question the Government's strategy and to promote legalization. Mainly he opposed the use of military forces in matters of internal security and saw that continuing the strategy would imply "bearing the sins of others" (El Tiempo, 1979d). For this reason, the senator also supported the initiative of legalization, so that Colombia, in association with other Latin American countries, commercialized with consumer nations, warning that otherwise it would be very difficult to control illegal trade.

The moralist argument did not seem to fit and the drug issue was not publicly perceived as a problem by a broad sector of society and that, on the contrary, "the task was being done to a foreign country”. Judge Samuel Buitrago's speech is evidence of this, 
The State is going to have to change the way it is handling the drug problem, it has to change it, I don't know when, because that got out of hand and every person who is informed of the daily events realizes that we are doing work for a strange power (El Espectador, 1986 as cited in Tokatlian, 2000b, p. 158).

\subsubsection{From morality to institutional threat: the road to agenda consolidation}

Given that the so-called morals and co-responsibility seemed to have no echo, the consolidation of the policy begins to open another argumentative path. One associated with the threat to institutional stability that the drug problem posed. A greater role of the "new emerging class", the corruption and weakening of the State - especially of its armed apparatus - and the loss of judicial sovereignty were the factors that began to generate unrest in the traditional political class.

The criticism was that drug trafficking corrupted and distracted the government and the military from more relevant and threatening issues for the state, as was reported at the time:

Colombia's top military officials have never concealed their displeasure at the anti-marijuana campaign... They believe it moves the army away from its main function, which is to watch over national security, and privately expressed their fear that soldiers could be corrupted by drug traffickers (El Tiempo, 1980, p. 6A).

The opposition discourse began to reflect this modification in the discussion. Ernesto Samper, who defended legalization, began to express concern that drug trafficking, and the emerging class that came with it, could be a serious threat to the privileges of the traditional class and, moreover, a serious challenge to the already fragile institutional stability of the country. For him,

\footnotetext{
We are, at the end of the day, between recognizing the mafias and re-routing them or being unknown to them and misrouting us all. Just as we suggested exactly a year ago the legalization of marijuana as the only way to legitimize this income, so it seems convenient to us today to propose the need to give the subterranean capitals institutional valves of escape... to avoid that, by their permanence in clandestinity, these capitals and their owners put an end to our institutions and ourselves (Samper, 1980, p. 22).
}

The new discourse can be summarized with the phrase of the sociologist Ibán De Rementería, who stated in the 80's: "the State does not persecute drug trafficking because it corrupts public health, but because corruption threatens the health of the State" (De Rementería, 1984, as cited in Arango \& Child, 1985).

\subsection{The agenda trigger: the assassination of Lara Bonilla}

In the public sphere, the shift from moral discussion to the debate about the institutional impact of drug trafficking was beginning to consolidate. However, the window of opportunity had not yet been given to introduce it to the core of the policy and thus solve the lack of public legitimacy. 
The policy entrepreneurs, headed by the Minister of Justice, Rodrigo Lara, and his political party, New Liberalism, adopted the term "hot money" to indicate the penetration of drug trafficking into the institutional life of the country. For the minister, these monies affected democracy, because of their proximity to the ruling class and the cooptation of the state; and their implications for the electorate, whose vote was undermined by the seduction of illegal money (Lara, 1983). Thus, since the minister took office in October 1983, repressive activities increased, as did the belligerent discourse against drug trafficking. This had its peak at the end of 1983, with the arrest warrant for Pablo Escobar, then a representative in the House of Representatives.

Thus, Minister Lara's efforts to strengthen and escalate the strategy made him the target of drug traffickers, who, unable to corrupt him, ultimately assassinated him in April 1984. From this historical fact, the government turns the official interpretation of the problem upside down, and begins to associate it directly with a threat to institutional order. The event shook the whole society, and worked as a trigger for the change of problem in the agenda, outlining a new line of argument, in force until today.

\subsection{Rethinking the problem: drugs as a national security problem}

For public opinion, the assassination of Minister Lara Bonilla showed that what was feared was true, and the consolidation of the social position of these new emerging groups could have serious consequences for the social order in terms of its destabilization and, even more worrying, in terms of the displacement of the traditional actors in power. This social upheaval was very skillfully used by the political actors in order to make a major shift in the understanding of the problem and, thus, obtain the legitimacy that they had long sought for the fight against drugs.

The problem is no longer seen as alien and politics begins to be understood as a pressing need to confront a threat to the institutional order of the Colombian state. In this way, the political and social support that the strategy imposed by the US government so badly needed was achieved; the advocacy actors were given legitimacy; and the need for repressive measures and criminal policy was justified.

This included the public acceptance of extradition as part of the repressive instruments of the policy, to the point that the president conceived it as a "legal instrument to combat impunity for criminal conduct, mainly in the face of the development of criminal forms that, because of their organization, resources, operational capacity and area of influence (...) endanger the international community" (Thoumi, 2006).

The change was immediate. In the funeral speech of Minister Lara Bonilla, President Betancur announced the declaration of a state of siege, which was formalized the following day by Decree 1038 of 1984, which was widely supported by different political parties. In the justification of the decree it is stated:

That, due to the persistent action of antisocial groups related to drug trafficking, the normal functioning of institutions in criminal defiance of Colombian society is being seriously disrupted, with its consequences for citizen security, public peace and health, and the national economy (Decree 1038 of 1984). 
The assimilation of this new discourse and the effect on the resistance towards politics that key actors had is very well observed in the change of position that previous contradictors, such as the High Courts, had towards extradition, as shown in Box 4.

BOX 4 COMMENTS OF JUDICIAL ACTORS IN FAVOR OF EXTRADITION.

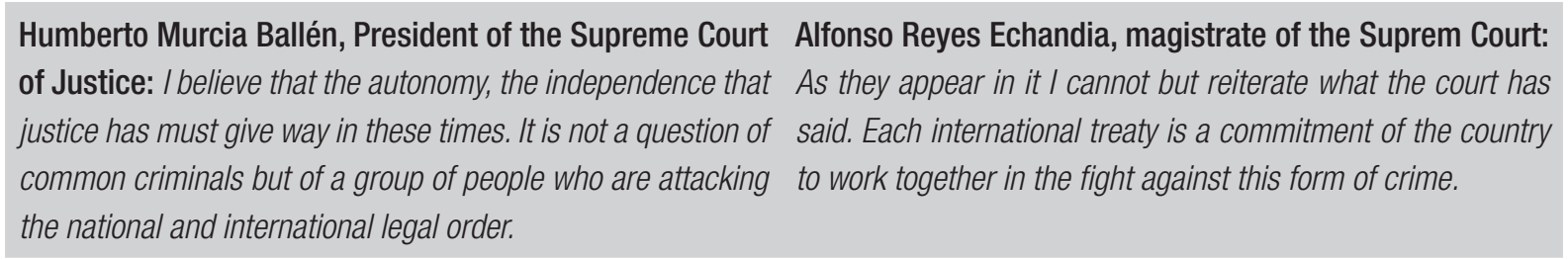

Source: El Tiempo (1984a, p. 14C).

Also, with the new discourse, public opinion no longer sees with good eyes the society of narcos with politicians, so the latter withdraw their visible support - although, of course, as history is going to show later, never the invisible ones-. Proof of this delegitimization can be observed in the call that President Betancur made during the funeral of Minister Lara, in which he expressed:

No more lounge gatherings for amusing comments on those who have just become rich with the trafficking of blood-stained coins! No more mud idols, raised in the shadow of poverty ready to unthinking gratitude for the dark gift of a park, of a school or of a medical formula... (Betancur, 1984, pp. 1A-1B).

The consolidation of the new discourse was also very useful for the U.S. government which, as one of the main political defenders, finally achieved a real commitment from Colombia in its fight against drugs. For Orozco Abad and Aponte (1992, p. 257), "the death of Lara Bonilla means, in this sense, the moment of the definitive internalization of the American model of national security in the criminal anti-drug policy".

The national security discourse also diminished the resistance of antagonistic actors (Cubides, 2004). And so, sectors such as the trade union, which previously expressed reservations, began to express themselves in favor of the strategy, as shown in the declaration of the National Federation of Merchants (Fenalco):

The sacrifice of Minister Rodrigo Lara Bonilla will not be useless, and his example "must penetrate very deeply into the conscience of all the Colombian people of good, who decidedly and energetically will close ranks to defend the patrimony that is more expensive to us: The moral and institutional values forged by our elders in so many efforts and during so many years... Rodrigo Lara went to sacrifice because of the special condition that Colombians themselves grant to illicit enrichment (El Tiempo, 1984b, p. 1A). 
Although the trigger for the process occurred in 1984, the political effort of consolidation continued. Thus, the process of institutionalization was extended during the Barco administration, which began in 1986 , and will condition the political trajectory until today. Since then, the internalization of the drug problem as a political issue in the country was consolidated, to the point that it could be considered one of the most preeminent issues for the subsequent governments. In the words of President Barco: "The fight against drug trafficking (...) is a real war for the survival of democratic institutions and the defense of the public freedoms of Colombians" (Soley, 2008, p. 59).

What happened in the Barco government, and subsequent governments, is that decisions on the drug issue are conditioned by the discourse that was forged on fighting an institutional threat where the repressive solution is necessary. Thus, being an issue that generated much resistance in its beginnings, the war on drugs became recognized as necessary for the stability of the country. By 1988, $75 \%$ of the population was already against the legalization of marijuana (Tokatlian, 2000a), making evident the acceptance of the prohibitionist policy. Both social acceptance and the conditioning of future policy decisions meet the theoretical criteria for stability of the core policy.

\section{DISCUSSION}

The evolution of the discourse in favor of the fight against drugs in Colombia, where it moves from a narrative of cooperation to one of threat to national security, shows the broad political efforts that the actors have to make in order to consolidate and maintain a public policy strategy. What was observed is that policy entrepreneurs employ multiple strategies that seek to give meaning and produce biases towards their favorite idea (Zahariadis, 2016), including important changes in narrative.

These consolidation and stability efforts go beyond containing the discussion, and rule out any passivity of the rulers or inertia as proposed in some approaches to public policy dynamics. In this special case, it was observed that drastic changes or reaffirming are also used to consolidate policies.

The political efforts are constant and occur on all fronts, both in the sub-government of politics and in the macro-structure of the political system. In this case, success allowed for an adequate government scenario, giving shape to the policy formulation process, and for an increase in the legitimacy of the defense actors (Peters, 2016). Thus, stability is explained in terms of the incremental return of power as observed in the way the new narrative fed the legitimacy of the executive, as well as that of the military forces and US government to intervene in the problem.

This case also reflects the fact that an important part of the political effort for stability is focused on building narratives that affect the collective interpretation of the policy. Mastering the shaping of the belief system is critical in the public politics dispute. As North (2007, p. 45) argues, "the beliefs held by humans determine the decisions they make, and these, in turn, structure the changes in the human landscape".

Therefore, it is not surprising that the reinvention of politics, associating it with a new problem, was a successful mechanism, because it managed to fit into the existing belief system an idea that was previously completely alien. Thus, the policy idea allowed the government entities to shape the government scenario and the process of policy formation in the matter.

Public policies are also a translation of the belief system of the actors (Weible \& Jenkins-Smith, 2016). Therefore, when the idea is external, many times the actors resist it, because they do not see 
in it their interpretation of the reality of the problem. This is what initially happened with the drug problem in Colombia. This challenge was solved with an important change in the discourse and the use of a timely political window.

It is also recognized that critical actors play a very important role in the consolidation of beliefs. Even if they do not have the capacity to transform, they have an impact by discussing the idea, which validates it, and by promoting a constant response from those who govern and defend the strategy. In this way, the narratives that form a stable system of beliefs around politics are constructed in dynamic ways and respond in an important way to the critical situation.

\section{CONCLUSIONS}

As can be seen, during the period analyzed it produced what was conceptualized as a cognitive mechanism for reinterpretation of the policy, where the narratives about the policy change so that the strategy continues, but associated to a new problem. This shows that policymakers and policy entrepreneurs can employ a wide repertoire of strategies to try to bring together problem and solution flows (Zahariadis, 2016). This change of discourse was intended to gain legitimacy and to become entrenched in the political agenda by coupling the strategy to the existing framework of beliefs, where the major concern was associated with institutional weakness and threats to national security.

An idea of public policy is more than a powerful cognitive instrument by which both citizens and political actors receive indications of how and why the government acts. This one also give order to the process of policy formulation (Peters, 2016) and, with their narratives distributed power loads and the actors manage to obtain positioning in the political scenarios of confrontation.

Thus, policies end up becoming important distributive instruments, with relevant political implications (Pierson, 2000), where the power is expressed in the ability to prolong the message and thus maintain the policy strategy according to interests. Thus, both the existence and permanence of the idea facilitate communication among actors, allowing them to initiate the formation of coalitions to defend their interests in the public spaces of deliberation.

The other relevant conclusion is that, definitely, the stability scenario is rarely a scenario of political inertia. Important are the efforts that must be made by the actors to activate the feedback processes, which, in addition, after their consolidation, require constant maintenance. The way in which politics succeeds in empowering the actors that support it will be fundamental in the dynamics of stability.

It is important to analyze in other cases of agenda formation reinterpretations or discursive reinventions or what other types of mechanisms of variation and adjustment are present and how the discourse and arguments are used to orient support around public policies for their stability. In these, the critical analysis of discourse can be use, since it is related to these purposes and allows an analysis of context and of the incidence of arguments in the distribution of power in the scenarios of sub-government of the policy and in the political control of agendas. 


\section{REFERENCES}

Aguilar, L. F. (2003). Estudio introductorio. In L. F. Aguilar (Ed.), Problemas políticos y Agenda de Gobierno. Ciudad de México, México: Grupo Editorial Miguel Angel Porrua.

Arango, M., \& Child, J. (1985). Los Condenados de la Coca: El Manejo Político de la Droga. Medellín, Colombia: Editorial J. M.

Baumgartner, F., \& Jones, B. (2002). Policy dynamics. Chicago, IL: University of Chicago Press.

Betancur, B. (1984, May 03). Colombia extraditará a criminales. El Tiempo, pp. 1A-1B.

Capano, G. (2009). Understanding Policy Change as an Epistemological and Theoretical Problem. Journal of Comparative Policy Analysis, 11(1), 7-31.

Capano, G., \& Howlett, M. (2009). Introduction: The Determinants of Policy Change: Advancing the Debate. Journal of Comparative Policy Analysis, 11(1), 1-5.

Cubides, F. (2004). Narcotráfico y Guerra en Colombia: Los paramilitares. In U. Nacional. (Ed.), Violencias y estrategias colectivas en la región andina: Bolivia, Colombia, Perú y Venezuela. Bogotá, Colombia: Editorial Norma, Instituto de Estudios Políticos y Relaciones Internacionales.

Denzau, A., \& North, D. C. (1994). Shared Mental Models: Ideologies and Institutions. Kyklos, 47(1), 3-31.

Eissler, R., Russell, A., \& Jones, B. D. (2016). The Transformation of Ideas: The Origin and Evolution of Punctuated Equilibrium Theory BT. In B. G. Peters, \& P. Zittoun. (Eds.), Contemporary Approaches to Public Policy: Theories, Controversies and Perspectives (pp. 95-112). London, UK: Palgrave Macmillan UK.

El Tiempo. (1979a, March 17). EE.UU. explica esfuerzo en control de drogas. El Tiempo, p. 8A.

El Tiempo. (1979b, March 17). Embajador de E.U. destaca campaña contra estupefacientes. El Tiempo, p. 8 A.

El Tiempo. (1979c, March 17). Contralor, partidario de legalizar la marihuana. El Tiempo, p. 14A.
El Tiempo. (1979d, September 19). Presidente del Senado: urge vender legalmente marihuana en el exterior. El Tiempo.

El Tiempo. (1979e, September 24). No se legalizará producción de marihuana: Turbay Ayala. El Tiempo, p. $10 \mathrm{~B}$.

El Tiempo. (1980, February 27). El ejercito se retirará de lucha contra las drogas. El Tiempo, p. 6A.

El Tiempo. (1984a, March 25). Jueces especiales para el narcotráfico. El Tiempo, p. 14C.

El Tiempo. (1984b, May 02). Ola de indignación en el país. El Tiempo, p. $1 \mathrm{~A}$.

Fairclough, N. (2003). Analysing Discourse: Textual Analysis for Social Research. London, UK: Routledge.

Gaviria, A., \& Mejía, D. (2011). Políticas antidrogas en Colombia: éxitos, fracasos y extravios. Bogotá, Colombia: Universidad de los Andes.

Greif, A., \& Laitin, D. D. (2004). A Theory of Endogenous Institutional Change. American Political Science Review, 98(4), 633-652.

Jacobs, A. (2010). Policymaking as Political Constraint . In J. Mahoney. (Ed.), Explaining Institutional Change (pp. 94-131). Cambrige, UK: Cambrige University Press.

Jones, B. (2002). Studying Policy Dynamics. In B. Jones. (Ed.), Policy Dynamics. Chicago, IL: University of Chicago Press.

Kay, A. (2009). Understanding Policy Change as a Hermeneutic Problem. Journal of Comparative Policy Analysis, 11(1), 47-63.

Kingdon, J. (1984). Agenda Setting. In S. Z. Theodoulou, \& M. A. Cahn. (Ed.), Public Policy: The Essential Readings (pp. 105-113). Upper Saddle River, NJ: Prentice Hall.

Lara, R. (1983). Narcotráfico: Uno de los problemas más graves del país, 26 de Octubre. In M. Arango, \& H. Barbosa. (Eds.), Colección Pensamiento liberal (p. 198). Bogotá, Colombia: Imprenta Departamental Antonio Nariño.

León, A., Rojas, D. M., Atehortúa, A. L., \& Rojas, D. M. (2008). El Narcotráfico en Colombia. Pioneros y Capos. Historia y Espacio, 4(31), 1-27. 
Lindner, J. (2003). Institutional Stability and Change: Two Sides of the Same Coin. Journal of European Public Policy, 10(6), 912-935.

Majone, G. (1989). Evidencia, Argumentación y Persuación en la Formulación de Políticas. México, DC: Fondo de cultura Económica.

Majone, G. (1996). Public policy and administration: ideas, interests and institutions. In H. D. Klingemann. (Ed.), A new hand book of political science (pp. 610627). Oxford, UK: Oxford.

North, D. C. (2007). Para Entender el Proceso de Cambio Económico. Bogotá, Colombia: Norma.

Orozco Abad, I., \& Aponte, A. D. (1992). Combatientes, rebeldes y terroristas: guerra $y$ derecho en Colombia. Bogotá, Colombia: Instituto de Estudios Políticos y Relaciones Internacionales de la Universidad Nacional.

Peñaranda, L. (2009). Tres Décadas de Noticias en la Prensa Colombiana sobre Drogras Ilícitas. Bogotá, Colombia: Universidad del Rosario.

Pereira, C., Singh, S. P., \& Mueller, B. (2011). Political Institutions, Policymaking, and Policy Stability in Latin America, 53(1), 59-89.

Peters, B. G., \& Zittoun, P. (2016). Contemporary Approaches to Public Policy: Theories, Controversies and Perspectives. London, UK: Palgrave Macmillan UK. Retrieved from https://doi.org/10.1057/978-1137-50494-4

Peters, G. (2016). Institutionalism and Public Policy. In B. G. Peters, \& P. Zittoun. (Eds.), Contemporary Approaches to Public Policy: Theories, Controversies and Perspectives (pp. 57-72). London, UK: Palgrave Macmillan UK.

Pierson, P. (2000). Increasing Returns, Path Dependence, and the Study of Politics. American Political Science Review, 94(2), 251-268.

Polski, M., \& Ostrom, E. (1999). An Institutional Framework for Policy Analysis and Design. Workshop in Political Theory and Policy Analysis. Bloomington, Indiana: Department of Political Science, Indiana University.

Rayner, J. (2009). Understanding Policy Change as a Historical Problem. Journal of Comparative Policy Analysis, 11(1), 83-96.
Real-Dato, J. (2009a). Mechanisms of Policy Change: A Proposal for a Synthetic Explanatory Framework. Journal of Comparative Policy Analysis, 11(1), 117-143.

Real-Dato, J. (2009b). Mechanisms of Policy Stability and Change: epistemological and theoretical implications of the application of the Institutional Analysis and Development Framework to the analysis and explanation of policy dynamics. In Proceeding of 21st World Congress of Political Science, Santiago de Chile, Chile.

Reynares, J. M. (2017). Cambio institucional, discurso y política. Una propuesta de análisis desde el postestructuralismo. Desafíos, 29, 199-236.

Sabatier, P. (1988). An Advocacy Coalition Framework of Policy Change and the Role of Policy-Oriented Learning Therein. Policy Sciences, 21(2/3), 129-168.

Sabatier, P. (2007). The Need for Better Theories. In P. A. Sabatier (Ed.), Theories of the Policy Process (pp. 3-20). London, UK: Routledge.

Sabatier, P., \& Jenkins-Smith, H. (1999). The Advocacy Coalition Framework: An Assessment. In P. Sabatier (Ed.), Theories of the Policy Process (pp. 117-166). Boulder, CO: Westview Press.

Sabatier, P., \& Weible, C. M. (2007). The Advocacy Coalition Framework: Innovations and Clarifications. In P. A. Sabatier (Ed.), Theories of the Policy Process (pp. 189-222). Boulder, CO: Westview Press.

Samper, E. (1979). Marihuana: Entre la Represión y la Legalización. In ANIF (Ed.), Marihuana: Mito y Realidad. Bogotá, Colombia: Author.

Samper, E. (1980). Los Subrepresentados. In ANIF (Ed.), La Abstención (p. 21). Bogotá, Colombia: Author.

Santander, J. (2009). Análisis de los Determinantes del Surgimiento y Consolidación de una Economía Ilegal. Centro Interdisciplinario de Estudios sobre el Desarrollo (CIDER). Bogotá, Colombia: Universidad de los Andes.

Santos Calderon, E. (1979, March 11). Legalizar la marihuana: crece la audiencia. El Tiempo, p. 5A.

Sarmiento, L., \& Moreno, C. (1990, FebruaryMarch). Narcotráfico y Sector Agropecuario en Colombia. Economía Colombiana, 226(27), 37. 
Schlager, E. (2007). A Comparison of Frameworks, Theories, and Models of Policy Processes. In P. A. Sabatier. (Ed.), Theories of the Policy Process (pp. 293-320). Boulder, CO: Westview Press.

Soley, N. (2008). El papel de las Fuerzas Armadas en la política antidorgas colombiana 1985-1990. In A. Vargas. (Ed.), El papel de las Fuerzas Armadas en la Política Antidrogas Colombiana 1985-2006 (pp. 41-72). Bogotá, Colombia: Universidad Nacional.

Sven Steinmo, K. T., \& Longstreth, F. (1992). Structuring Politics. Cambridge, UK: Cambridge University Press.

Thelen, K. (1999). Historical Institutonalism in Comparative Politics. Annual Review Political Science, 2, 369-404.

Thelen, K. (2010). A theory of gradual institutional change. In K. Thelen. (Ed.), Explaining Institutional Change Ambiguity, Agency, and Power (pp. 1-37). Cambridge, UK: Cambridge University Press.

Thoumi, F. (2006). Las Políticas contra las Drogas, Reformas y Relaciones Colombo - Americanas. In A. Camacho. (Ed.), Narcotráfico: Europa, Estados Unidos, América Latina. Bogotá, Colombia: Ediciones Uniandes.

Thoumi, F. (2009, July-August). La Normatividad Internacional sobre Drogas como Camisa de Fuerza. Nueva Sociedad, 222.

Tilly, C. (2001). Mechanisms in Political Processes. Annual Review of Political Science, 4(1), 21-41.

Tokatlian, J. G. (1990). Colombia hacia Estados Unidos: 1978 - 1990. El asunto de las drogas y su lugar en las relaciones entre Bogotá y Washigton. In C. Arrieta, \& L. J. Orjuela. (Eds.), Narcotráfico en Colombia. Bogotá, Colombia: Ediciones UniandesTercer mundo editores.

Tokatlian, J. G. (2000a). Globalización, narcotráfico y violencia: siete ensayos sobre Colombia. Colección vitral; Colección biografías y documentos; Colección biografías y documentos. Bogotá, Colombia: Grupo Editorial Norma.

Tokatlian, J. G. (2000b). La polemica sobre la legalizacion de drogas en Colombia, el Presidente Samper y los Estados Unidos. The Latin American Studies Association, 35, 37-83.
True, J., Jones, B., \& Baumgartner, F. (2007). Punctuated-Equilibrium Theory: Explaining Stability and Change in Public Policymaking. In P. Sabatier, \& C. M. Weible. (Eds.), Theories of policy process (pp. 155-189). Boulder, CO: Westview Press.

Tsebelis, G. (2002). Veto players: how political institutions work. New York, NY: Princeton University Press.

Van Dijk, T. (2015). Critical Discourse Analysis. In D. Tannen, H. Hamilton, \& D. Schiffrin. (Eds.), The Handbook of Discourse Analysis (pp. 466-485). Chichester, UK: John Wiley \& Sons.

Vargas, R. (2010). Desarrollo Alternativo en Colombia y Participación Social. Bogotá, Colombia: Corcas Editores Ltda.

Weible, C. M., \& Jenkins-Smith, H. C. (2016). The Advocacy Coalition Framework: An Approach for the Comparative Analysis of Contentious Policy Issues BT. In B. G. Peters \& P. Zittoun. (Eds.), Contemporary Approaches to Public Policy: Theories, Controversies and Perspectives (pp. 15-34). London, UK: Palgrave Macmillan UK.

Weible, C. M., \& Sabatier, P. (2006). A Guide to the Advocacy Coalition Framework. In F. Fischer, G. J. Miller, \& M. S. Sidney. (Eds.), Handbook of Public Policy Analysis (pp. 123-136). Boca Raton, FL: CRC Press.

Weible, C. M., Sabatier, P., \& McQueen, K. (2008). Expert-Based Information and Policy Subsystems: A Review and Synthesis. Policy Studies Journal, 36(4), 615-635.

Weible, C. M., Sabatier, P., \& McQueen, K. (2009). Themes and Variations: Taking Stock of the Advocacy Coalition Framework. Policy Studies Journal, 37, 121-140.

Zahariadis, N. (2007). The Multiple Streams Framework: Structure, Limitations, Prospects. In P. Sabatier (Ed.), Theories of the Policy Process (pp. 65-92). Boulder, CO: Westview Press.

Zahariadis, N. (2016). Bounded Rationality and Garbage Can Models of Policy-Making. In B. G. Peters \& P. Zittoun. (Eds.) Contemporary Approaches to Public Policy: Theories, Controversies 
RAP | Narrative reinventions as cognitive mechanisms for public policy stability: the case of anti-drug policy in Colombia

and Perspectives (pp. 155-174). London, UK: Palgrave Macmillan UK. Retrieved from https://doi. org/10.1057/978-1-137-50494-4_9
Zittoun, P. (2009). Understanding Policy Change as a Discursive Problem. Journal of Comparative Policy Analysis: Research and Practice, 11(1), 65-82.

\section{Jairo Santander}

https://orcid.org/0000-0002-5822-6489

Ph.D. in Political Science; Assistant professor in Centro Interdisciplinario de Estudios sobre Desarrollo (CIDER) at Universidad de los Andes. E-mail: Jsantand@uniandes.edu.co 